\title{
Left Ventricle Size, End-Systole, Quantitative
}

National Cancer Institute

\section{Source}

National Cancer Institute. Left Ventricle Size, End-Systole, Quantitative. NCI Thesaurus.

Code C80420.

A measurement obtained from a radiographic image of the left ventricle during the final moment of ventricular contraction, when the ventricle empties of blood. 